\title{
On the occurrence of Mesophyllum expansum (Philippi) Cabioch et Mendoza (Melobesioideae, Corallinales, Rhodophyta) in the Mediterranean Sea, the Canary Isles and the Azores
}

\author{
Athanasios Athanasiadis ${ }^{1, *}$ and Ana I. Neto ${ }^{2}$ \\ ${ }^{1}$ Marine Botany, Göteborg University, BOX 461, \\ 40530 Göteborg, Sweden, \\ e-mail: Athanasios.Athanasiadis@marecol.gu.se \\ ${ }^{2}$ Secção de Biologia Marinha, Departamento de Biologia, \\ Universidade dos Açores, Rua da Mãe de Deus Apartado \\ 1422, 9501-801 Ponta Delgada (Açores) Codex, Portugal \\ * Corresponding author
}

\begin{abstract}
We reviewed literature records, examined herbarium specimens and studied new collections referred to as Mesophyllum lichenoides from the Mediterranean and the North Atlantic, and report for the first time the presence of Mesophyllum expansum in the Canaries and the Azores. Both gametophytes and tetrasporophytes of $M$. expansum occur in the Canaries, while we found only tetrasporophytes (and sterile thalli) of the species in all other regions. We further consider the presence of $M$. lichenoides further south than Atlantic France in need of confirmation. A comparative study between these two species points to the number of rosette cells as the most reliable and easily diagnosed character, $M$. expansum most often having 9-11 and $M$. lichenoides 6-8 cells.
\end{abstract}

Keywords: Mesophyllum expansum; Mesophyllum lichenoides; Mesophyllum mesomorphum; taxonomy.

\section{Introduction}

Prior to 1983, the name Lithophyllum (Pseudolithophyllum) expansum Philipppi (1837) was applied to a common Mediterranean species of Lithophyllum widely occurring in both the western and eastern basins as well as the Adriatic Sea, until it was discovered that the type material had a multilayered and coaxial hypothallium (Woelkerling 1983: 307, figs 7, 8), a feature not in accord with the genus Lithophyllum but generally associated with species of Mesophyllum Lemoine or Neogoniolithon Setchell et Mason (e.g., Adey et al. 1982). Twenty more years were needed to establish that the species originally described by Philippi had also been subsumed in Mesophyllum lichenoides (Ellis) Lemoine, when in fact it should be recognized as an independent taxon, Mesophyllum expansum (Philippi) Cabioch et Mendoza
(2003). Despite these findings, the name M. lichenoides remained in use in the Mediterranean literature (e.g., Basso and Rodondi 2007, Taskin et al. 2008: 19, Braga et al. 2009: 120) without new evidence of the occurrence of this species in the Mediterranean Sea.

In the course of a study of the genus Mesophyllum in the tropics and the subtropics, we have searched for $M$. lichenoides along and off the Atlantic and Mediterranean coasts of Europe, and found instead $M$. expansum both in the Azores and the Canaries, and also in the Mediterranean Sea.

\section{Materials and methods}

Specimens from the herbaria BM, C, CAT, L, MICH, MSM, NY, PC, TFC, and TRH were examined under a Zeiss Stemi SV six microscope (Carl Zeiss, Jena, Germany). Photographs were taken using a Zeiss Axiophot 2 after the material had been decalcified using acetic acid (20-45\%, 5-24 h), stained/hardened in aniline blue (1-5\% solution with alcohol for at least $24 \mathrm{~h}$ ), and sectioned in Hamilton's freezing solution $(1 \mathrm{~g}$ gum arabic: $30 \mathrm{~g}$ sucrose: one crystal of thymol: $100 \mathrm{ml}$ distilled water) using a Kryomat 1700 freezing microtome (Leitz, Stuttgart, Germany), at a thickness of 30-50 $\mu \mathrm{m}$. For light microscopy, we used either the Zeiss Axiophot 2 or a Leitz Dialux 20 EB (Leitz, Toronto, Canada). Permanent slides were mounted in Karo syrup (60-80\%; Best Food Division CPC International, Englewood Cliffs, NJ, USA).

Terminology follows previous papers on coralline taxonomy (e.g., Athanasiadis et al. 2004). Rosette cells are the apical cells surrounding the canals of multiporate roofs. Number of measurements of characters appears in parenthesis (n: \#). Herbarium abbreviations follow Holmgren et al. (1990), and citations of Articles (Art.) refer to the latest International Code of Botanical Nomenclature (McNeill et al. 2006).

The collections of Mesophyllum expansum examined are cited in the Results, while the material of M. lichenoides examined is cited below.

British Isles: unlocated, tetrasporangial thalli on Corallina, 2 November 1921, coll. L. Lyle, 'Lithophyllum lichenoides', BM (box number 303). Jersey, Gifford Bay, male and carposporangial thalli, mid tide pools, 23 October 1984, coll. Y.M. Chamberlain, $\mathrm{n}^{\circ}$ 84/382, herb. Chamberlain, duplicate in herb. Athanas. and in GB (unnumbered).

France: Cabo Higuer, Navarra, male, carposporangial and tetrasporangial thalli on Gelidium, in pools well up the shore, 
24 October 1988, coll. Y.M. Chamberlain, $\mathrm{n}^{\circ}$ 88/102, BM (box number 2053), duplicate in herb. Athanas. and in GB (unnumbered). - Trez-Hir, Brest, 18 August 1992, on rocks, extensive populations of tetrasporangial thalli on Corallina, in the intertidal and below fucoids, coll. A. Athanasiadis, in herb. Athanas., duplicate in GB (unnumbered). - Roscoff and Finistère, end of July and August 1932, and start of August 1936, tetrasporangial thalli, coll. E. Chemin, slides in herb. Suneson $n^{\circ}$ ' $114 / 37 \mu$ ', GB (unnumbered).

\section{Results and discussion}

\section{Mesophyllum expansum (Philippi) Cabioch et Mendoza (2003: 259)}

Basionym Lithophyllum expansum Philippi (1837: 389).

\section{Type locality Sicily.}

Lectotype In L, '9395 n²', designated herein; illustrated in Woelkerling (1983): 308, fig. 4, larger specimen) and in Cabioch and Mendoza (2003: 262, fig. 2A).

Homotypic synonyms ${ }^{1}$ Melobesia expansa (Philippi) Endlicher (1843: 49). Lithothamnion expansum (Philippi) Foslie (1895: 177). Lithophyllum expansum $\mathrm{f}$. genuinum Foslie (1897: 3). Tenarea expansa (Philippi) Kuntze (1898: 433). Hyperantherella expansa (Philippi) Heydrich (1901: 192). Stereophyllum expansum (Philippi) Heydrich (1904: 198). Crodelia incrustans var. expansa (Philippi) Heydrich (1911: 13). Pseudolithophyllum expansum (Philippi) Lemoine (1924: 114, 122). Crodelia expansa (Philippi) Kylin (1956: 208).

Misapplied names Mesophyllum lichenoides sensu Lemoine in Børgesen (1929: 31, Canaries, material in C). According to the results of this study. Mesophyllum lichenoides sensu Neto (1994: 26, Azores). Melobesia stictaeformis sensu Bornet in herb. (material from Antibes, Mediterranean France, in PC). According to Cabioch and Mendoza (2003: 259). Mesophyllum lichenoides sensu Lemoine in herb. (material from Mediterranean France, in PC). According to Cabioch and Mendoza (2003: 259). Pseudolithophyllum expansum sensu Feldmann in herb. (material from Mediterranean France, in PC). According to Cabioch and Mendoza (2003: 259).

\footnotetext{
${ }^{1}$ Between 1843 and 1956, Lithophyllum expansum was transferred to different ranks and genera, in most cases to accommodate a species of Lithophyllum currently known as L. stictaeforme (Areschoug) Hauck (Athanasiadis 1999b). However, we have not examined any relevant collections from the herbaria Endlicher, Foslie, Kuntze, Heydrich, Lemoine or Kylin, to confirm this. Material of Crodelia expansa sensu Levring (1974: 65) from Madeira was not found at GB (Andersson and Athanasiadis 1992) and Levring's duplicate collection deposited at 'Museu Municipal' in Funchal was not examined in the present study. It should be noted, however, that Levring's description 'Found a few times on exposed rocks near low water line and in pools....Funchal (Baixa Larga, Club Naval)' matches the habitat preferences of Mesophyllum expansum.
}

Material examined Aegean: Sithonia, Pigeon Cave, 1-2 m depth, 20 June 2006, sterile, coll. A. Athanasiadis, herb. Athanas. 'SC.20.06.02', GB (unnumbered). - Sicily: Catania, S. Maria La Scala, 17 July 1999, tetrasporangial thalli, coll. unknown, CAT (unnumbered). - Mediterranean Spain: Catalonia: Cap de Creus: 0 m, 30 November 2003, sterile, coll. C. Rodriguez-Prieto, GB (unnumbered); $25 \mathrm{~m}$, coralligène, 30 November 2003, tetrasporangial thalli, coll. C. Rodriguez-Prieto, GB (unnumbered); Cap Gros, Palamós, 25 m, coralligène, sterile, 25 January 2004, coll. C. Rodriguez-Prieto, GB (unnumbered); Plaja d'Aro, $30 \mathrm{~m}$, coralligène, 21 December 2003, sterile, coll. C. Rodriguez-Prieto, GB (unnumbered); Illes Formigues, Palamós, 30 m, coralligène, undated, tetrasporangial thalli, coll. C. Rodriguez-Prieto, GB (unnumbered); 35 m, coralligène, 21 December 2003, sterile, coll. C. Rodriguez-Prieto, GB (unnumbered); Mon de Fora, Palamós, 35 m, coralligène, 1 February 2004, sterile, coll. C. Rodriguez-Prieto, GB (unnumbered).

Canary Islands: Tenerife, Puerto de la Cruz, 9 January 1921, sterile crust on Haliotis, coll. Børgesen $\mathrm{n}^{\circ} 3109, \mathrm{C}$ (unnumbered, as 'x Mesophyllum lichenoides (Ell.) Lem.', growing with 'o Pseudolithophyllum Esperi très jeune' and 'v Lithothamnium ectocarpon Fosl.'; 26 January 1921, tetrasporangial and sterile thalli, unattached, coll. Børgesen $\mathrm{n}^{\circ} 3277, \mathrm{C}$ (unnumbered); 26 January 1921, carposporangial thalli, unattached, coll. Børgesen $n^{\circ} 3278, \mathrm{C}$ (unnumbered); July 1979, 'Paredes verticales infralitoral', tetrasporangial thalli, coll. J. Afonso-Carrillo, TFC 2548; 21 June 1981, ' 2 m profundidad', tetrasporangial thalli, coll. J. Afonso-Carrillo, TFC 2546; 14 November 1981, 'Charco mesolitoral', 'Talo femenino', gametangial thalli, coll. J. Afonso-Carrillo, TFC 2585; Tenerife, Puerto de la Cruz, February 1980, 'Oquedad mesolitoral', 'Masculino', tetrasporangial thalli, coll. J. Afonso-Carrillo, TFC 2549.

Azores: Pico: Cais do Pico, 'Mesophyllum lichenoides?', submerged, 31 August 1971, tetrasporangial thalli, coll. Botelho Gonçalves, $\mathrm{n}^{\circ}$ 388, BM (box coll. 1534); Graciosa: Sta. Cruz, Pta da Barra, $5 \mathrm{~m}$, exposed, bedrock with sand influence, epilithic, 24 June 2006, tetrasporangial thalli, coll. Karla Cisneros and Ruben Couto (duplicate in GB, unnumbered); Baia da Fonte, $30 \mathrm{~m}$, exposed, boulders with sand influence, epilithic, 9 July 2006, tetrasporangial thalli, coll. Nuno V. Alvaro and André Amaral (duplicate in GB, unnumbered); São Miguel: Porto da Caloura, 5 m, exposed, bedrock with sand influence, epilithic, 19 February 2008, tetrasporangial thalli, coll. Nuno V. Alvaro and André Amaral (duplicate in GB, unnumbered).

'West Indies': undated, unlocalized, sterile, coll. unknown, 'No 9 L. lichenoides f. agariciformis', 'Melobesia', 'Bk', BM (box number 216).

Morphology Thalli at least $12 \mathrm{~cm}$ in extent and $2.3 \mathrm{~cm}$ in thickness (Sicilian specimens including the lectotype), adhering lightly to shells, or pebbles (as young individuals) and progressively forming larger complexes attached to various substrata (including corallines). Well-developed thalli mainly unattached with regular superposition of new lamellae. Thallus surface flattened to undulate, pinkish to deep 


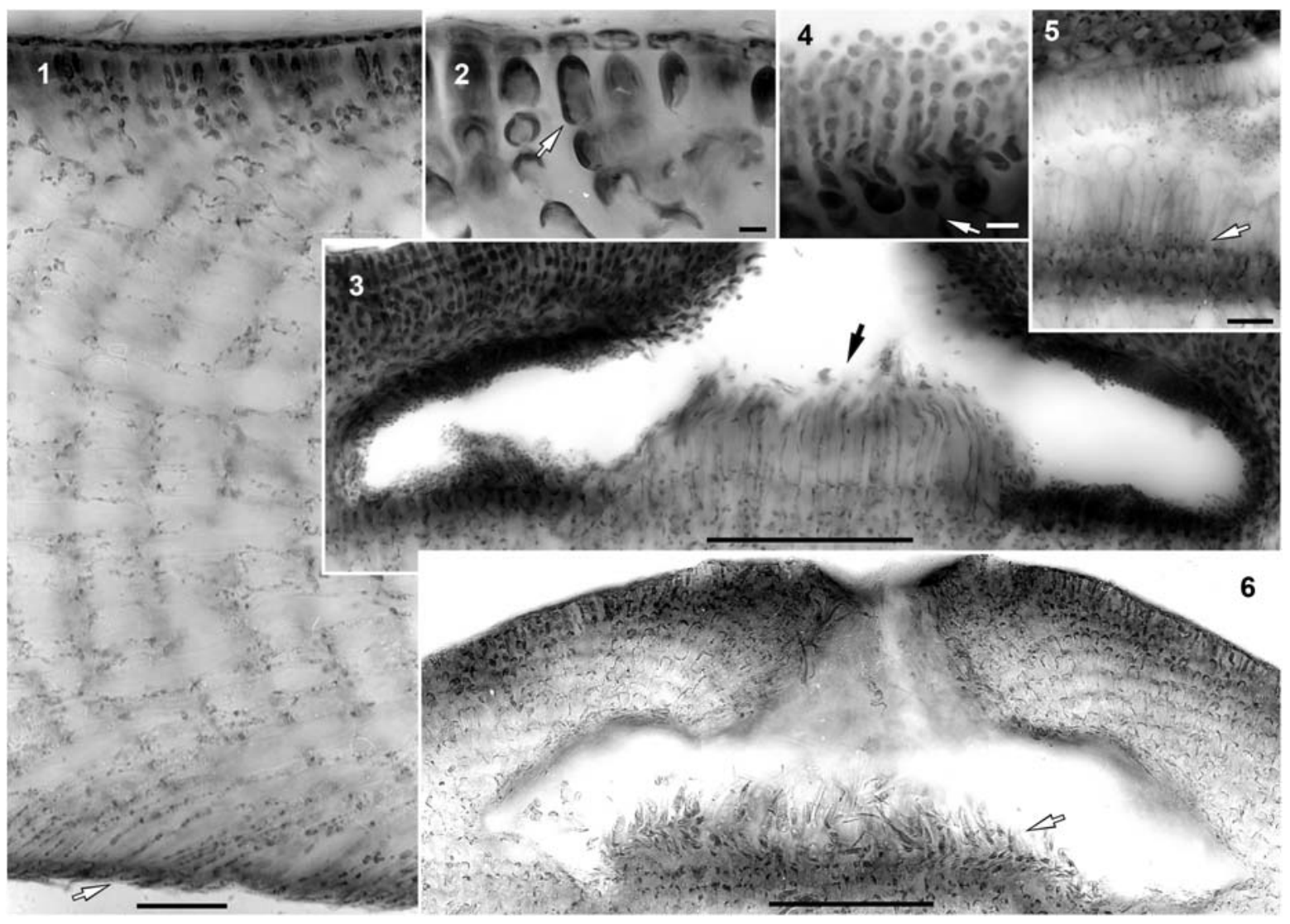

Figures 1-6 Mesophyllum expansum.

Longitudinal section of a thallus showing a coaxial, arching hypothallium producing a few layers of ascending perithallial cells terminating in single epithallial cells, and descending hypothallial cells ending in wedge-shaped cells (arrow) (scale bar $=50 \mu \mathrm{m}$; Graciosa, Baia da Fonte, Azores; GB). (2) Elongate subepithallial cells (arrow) supporting flattened epithallial cells (scale bar=5 $\mu \mathrm{m}$; Orotava, on Haliotis, Canaries; C, herb. Børgesen $n^{\circ}$ 3109). (3) Section through a male (hermaphroditic) conceptacle, showing a group of carpogonial branches in the floor center (arrow) and spermatangial structures on the periphery and the roof (scale bar=125 $\mu \mathrm{m}$; Puerto de la Cruz, Canaries; TFC 2549). (4) Typical lunate spermatangial mother cells (SMCs) on the floor (arrow) producing spermatangia (scale bar=5 $\mu \mathrm{m}$; Puerto de la Cruz, Canaries; TFC 2549). (5) Section through a male conceptacle at a late stage, when spermatangial structures have been replaced by palisade cells (arrow) both on the floor and the roof, supporting remains of spermatangial walls (scale bar=25 $\mu \mathrm{m}$; Puerto de la Cruz, Canaries; TFC 2549). (6) Section through an empty carposporangial conceptacle, showing the elevated central floor ('pedestal'; arrow) with remains of carpogonial branches (scale bar $=125 \mu \mathrm{m}$; Puerto de la Cruz, Canaries; TFC 2549).

red, becoming grayish or bleached in older herbarium specimens. Examined thalli from the Canaries and the Azores up to $5 \mathrm{~cm}$ in extent. All conceptacles distinctively raised with convex to flattened roof (in transverse section). Multiporate conceptacles with obvious pore openings (whitish), gradually deteriorating after spore discharge.

Anatomy Individual lamellae dorsiventrally organized, 280-640 $\mu \mathrm{m}$ thick, with a predominantly coaxial, arching hypothallium 200-500 $\mu \mathrm{m}$ thick, giving rise to an ascending, locally stratified perithallium 70-100 thick $\mu \mathrm{m}$ (Figure 1) (perithallium up to $150 \mu \mathrm{m}$ according to Cabioch and Mendoza 2003). Hypothallial cells (15)20-46 $\mu \mathrm{m}$ long [30-60 $\mu \mathrm{m}$ long in the type according to Woelkerling (1983); $50 \mu \mathrm{m}$ according to Cabioch and Mendoza (2003)] and 5-8 $\mu \mathrm{m}$ broad [ $8-14 \mu \mathrm{m}$ in the type according to Woelkerling (1983); $20 \mu \mathrm{m}$ according to Cabioch and Mendoza (2003)]; perithallial cells 8-16 $\mu \mathrm{m}$ long and 5-10 $\mu \mathrm{m}$ broad
[11-30×6-10 $\mu \mathrm{m}$ in the type according to Woelkerling (1983); 10-15×4-5 $\mu \mathrm{m}$ according to Cabioch and Mendoza (2003)], with elongate subepithallial cells 11-16 $\mu \mathrm{m}$ long, each supporting a single, usually flattened epithallial cell, 1-3 $\mu \mathrm{m}$ long and $7-11 \mu \mathrm{m}$ in diameter (Figure 2) [8-14×4-8 $\mu \mathrm{m}$ in the type according to Woelkerling (1983)]. Cell fusions common between contiguous perithallial or hypothallial cells. Trichocytes absent.

Reproduction Gametangial thalli generally dioecious, but hermaphroditic conceptacles also seen. Male conceptacles 440-800 $\mu \mathrm{m}$ in external diameter and 70-90 $\mu \mathrm{m}$ high, with chambers $410-625 \mu \mathrm{m}$ in diameter and 60-120 $\mu \mathrm{m}$ high, and a roof 65-110 $\mu \mathrm{m}$ thick (n: 9). Spermatangial mother cells (SMCs) simple, lunate, occurring on the floor, the walls and the roof (Figures 3 and 4), deteriorating with age and forming palisade cells supporting remains of spermatangial walls (Figure 5). A few hermaphroditic male 

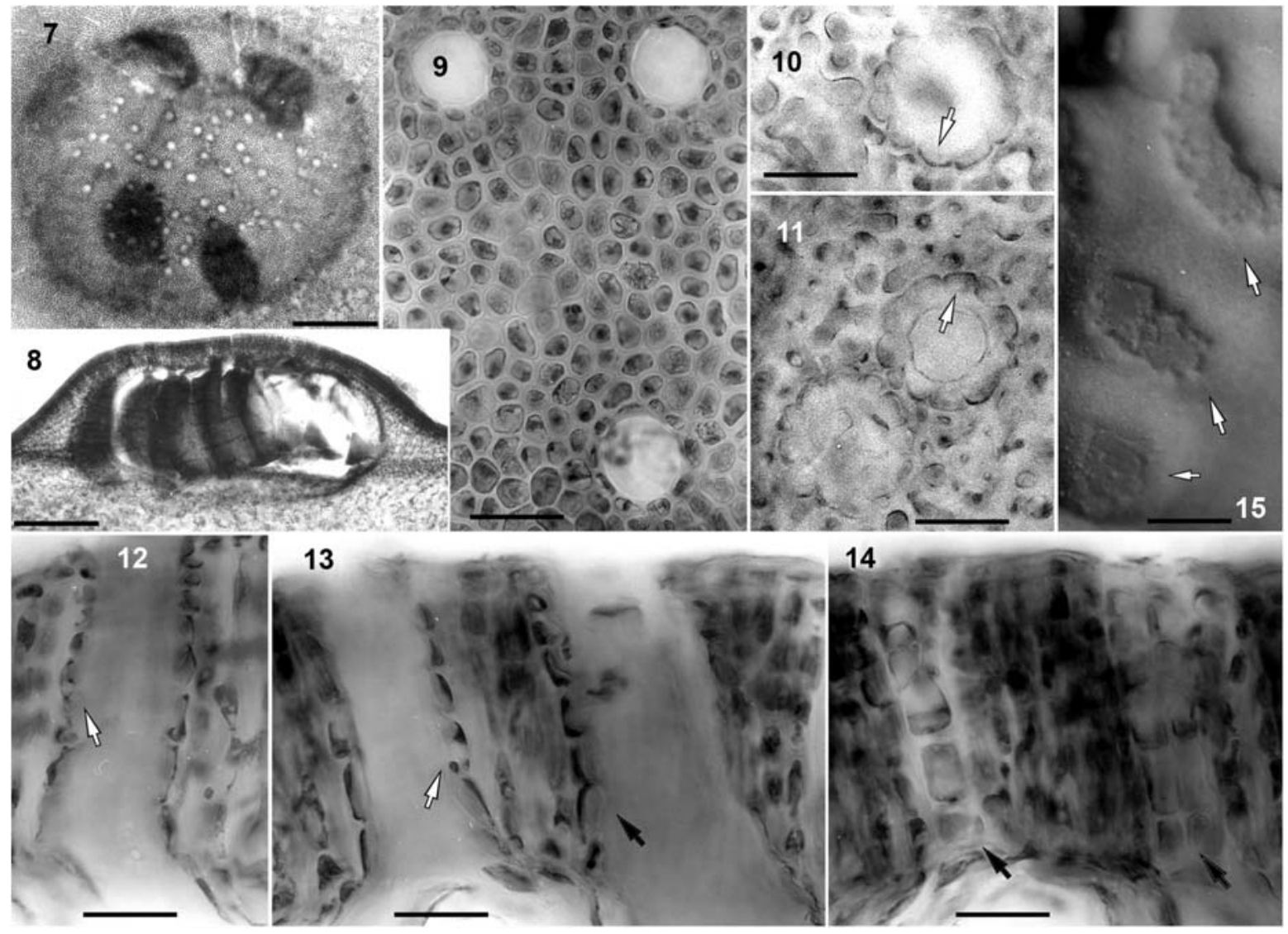

Figures 7-15 Mesophyllum expansum.

(7) Surface view of a multiporate roof with tetrasporangia in the chamber (scale bar $=250 \mu \mathrm{m}$; Catania, Sicily; CAT). (8) Section through a tetrasporangial conceptacle, showing a typically flattened/convex roof and zonately divided tetrasporangia (scale bar=250 $\mu \mathrm{m}$; Pico, Azores; BM). (9) View of a multiporate roof from above, showing three pore canals, each surrounded by 11, 11, and 10 rosette cells, respectively (scale bar: $25 \mu \mathrm{m}$; Graciosa, Baia da Fonte, Azores; GB). (10-11) Views of multiporate roofs from above at a lower level of focus, showing three canals surrounded by 'thinner-wider' pore cells (arrows) (scale bars: $25 \mu \mathrm{m}$; Graciosa, Baia da Fonte, Azores; GB). (12-14) Shape variation of pore cells lining canals. Both normal roof cells (Figures 12, 13; white arrows) and 'thinner-wider' (Figures 13, 14; black arrows) pore cells are present (scale bars: $25 \mu \mathrm{m}$; Orotava, Canaries; C, herb. Børgesen ${ }^{\circ}$ 3277). (15) Surface view of deteriorating multiporate conceptacles, where the crater-like remains of the chamber are progressively covered (arrows) (scale bar: $500 \mu \mathrm{m}$; Graciosa, Baia da Fonte, Azores; GB).

conceptacles occasionally seen, displaying (unfertilized) carpogonial branches in the center of the floor (Figure 3).

Carposporangial conceptacles 600-940 $\mu \mathrm{m}$ in external diameter and 150-320 $\mu \mathrm{m}$ high, with chambers 390$600 \mu \mathrm{m}$ in diameter and 170-210 $\mu \mathrm{m}$ high (n: 7), and a centrally raised fertile floor ('pedestal') (Figure 6). Carpospores, 50-200 $\mu \mathrm{m}$ long and 50-100 $\mu \mathrm{m}$ broad, cut-off from the periphery. Roof $75-125 \mu \mathrm{m}$ thick, with a central $100-125 \mu \mathrm{m}$ long ostiole, $80-100 \mu \mathrm{m}$ in diameter at the base and ca. $40 \mu \mathrm{m}$ at the apical opening.

Multiporate conceptacles raised, $850-1300 \mu \mathrm{m}$ in external diameter (reaching $1600 \mu \mathrm{m}$ when two merge) and 250$400 \mu \mathrm{m}$ high (n: 13) [up to $1500 \mu \mathrm{m}$ in external diameter according to Cabioch and Mendoza (2003)], with flattened or convex roof, $50-80 \mu \mathrm{m}$ thick, perforated by $50-67$ pores (n: 6) [30-50 according to Cabioch and Mendoza (2003)] (Figures 7 and 8). Chambers $610-800 \mu \mathrm{m}$ in diameter and 310-400 $\mu \mathrm{m}$ high (n: 3) [650-700 $\times 350 \mu \mathrm{m}$ according to Cabioch and Mendoza (2003)]. Pore plates $470-750 \mu \mathrm{m}$ in diameter (n: 7). Roof filaments composed of 5-7 cells. Pore openings $15-22 \mu \mathrm{m}$ in diameter at the surface and $30-40 \mu \mathrm{m}$ at the base (n: 9) (Figures 9-11). Pore openings surrounded by (8)9-11(12) rosette cells [frequency: 8 (4.2\%), 9 (32.1\%), 10 (40.1\%), 11 (20.2\%), 12 (3.4\%); n: 237], which are either normal-size epithallial cells or thinnerwider (in the former case, flush with the surface, and in the latter, terminating below). Pore cells lining the canals differentiated or not, composed of 6-10 celled filaments, with cells increasing in size towards the base and occasionally 'thinner-wider' (Figures 12-14). Tetrasporangia 180-300 $\mu \mathrm{m}$ in length and 50-150 $\mu \mathrm{m}$ broad (n: 7). Embedded conceptacles not seen (as they deteriorate with age; Figure 15).

\section{Comments on the protologue, the type collection and lectotypification Philippi's (1837) protologue reads} '...Lithophyllum expansum mihi. L. supra pallidum, subtus discolor, album; lamellis maximis, expansis, horizontalibus, subimbricatis, orbicularibus; marginis lobis obtusissimis inte- 
gris. Pocillopora agariciformis Ehrenb. Beitr. z. Kenntn. der Corallenth. p. 129? excl. syn. «membranacea, latere affixa, libera, suborbicularis». Mein grösstes Exemplar ist $4 \frac{1}{2}{ }^{\prime \prime}$ lang und 3" breit.' This reads in translation: 'Lithophyllum expansum to me [is] a Lithophyllum with pale surface, and partly colored underside, whitish; lamellae mostly horizontally expanded, more or less imbricate (superimposed), circular; margins lobate, mostly blunt and entire. Pocillopora agariciformis Ehrenb. Beitr. z. Kenntn. der Corallenth. p. 129? excl. syn. «membraneous, laterally attached, free, more or less circular» - My largest specimen is $11.25 \mathrm{~cm}$ long and $7.5 \mathrm{~cm}$ broad.' (Philippi's measurements refer to pollex, the terminal joint of the thumb. One pollex equals $2.5 \mathrm{~cm}$; see Kützing 1849: vi, Stearn 1986: 487).

As Philippi questioned the synonymy with Pocillopora agariciformis Ehrenberg, Lithophyllum expansum Philippi is a valid and legitimate name (Art. 52. Note: 1).

According to Woelkerling, the type material in Leiden consists of two specimens that 'at some stage probably [were] part of [one] piece' (Woelkerling 1983: 307-8, fig. 4). Yet, this has not been demonstrated and therefore the two pieces should rather be considered as separate specimens. The entire material was first cited as 'Lectotype collection' or 'lectotype element' (Woelkerling 1983: 307), later as 'holotype' (Woelkerling and Verheij 1995: 51, 'because only a single specimen is involved') and more recently as 'échantillon lectotype ..constitué de deux morceaux..' '..specimens que nous avons examinés..' (Cabioch and Mendoza 2003: 263). The larger specimen illustrated in greater magnification by Cabioch and Mendoza (2003: 262, fig. 2A) is here designated as the lectotype (the smaller one, including fragments in the box, become syntypes), for reasons given below.

The examination of the type material by Woelkerling (1983: 307-313, figs 4-14) showed that Lithophyllum expansum possessed a coaxial, arching, multilayered hypothallium and cell fusions between contiguous somatic cells (Woelkerling 1983: figs 8, 11, 12). This character combination definitely excluded the species from Lithophyllum, supporting an affiliation either with the genus Mesophyllum (Melobesioideae) or Neogoniolithon (Mastophoroideae). Subsequently, Cabioch and Mendoza (2003) documented the presence of a dorsiventral organization, a thin perithallium, elongate subepithallial cells, flattened epithallial cells, and lack of trichocytes, and after comparing the (here selected) lectotype with (tetrasporangial and sterile) material from Corse, Antibes, Endourme, Marseille and Villefranche sur Mer, concluded that the species was a member of Mesophyllum. Cabioch and Mendoza (2003) could not find any conceptacles on the type specimens, but Woelkerling (1983, figs $5,6,14)$ described and illustrated the presence of four male conceptacles ca. $444 \mu \mathrm{m}$ in diameter and $300 \mu \mathrm{m}$ high, one occuring on the smaller (syntype) specimen, the other on minor fragments (in the box). He also documented the content in one of the conceptacles suggesting that the remains seen in SEM were spermatangia ('occurr[ing] in the ostiole'). Such conceptacles are quite different in size and shape, and spermatangial distribution from those documented here for the species (from the Canary Isles) or the genus in general (e.g., Athanasiadis et al. 2004, figs 42, 60, 116), and therefore we have here excluded the syntype as representative of L. expansum - motivating the lectotypification (Art. 9.2).

\section{Comments on the structure and reproduction of the} species Cabioch and Mendoza (2003) provided additional information on the anatomy of pore canals and epithallial cells to support the distinction of Mesophyllum expansum from $M$. lichenoides, whose presence in the Mediterranean may now be questionable (remains to be confirmed). The latter authors also showed that two different species and genera were previously confused under the name Lithophyllum (Pseudolithophyllum) expansum in the Mediterranean Sea: a species of Lithophyllum currently known as L. stictaeforme and $M$. expansum, both possessing a similar habit. Yet, $M$. expansum is not as robust as L. stichaeforme and also adheres lightly to the substratum. Under the binocular microscope, the presence/absence of a coaxial hypothallium easily differentiates the two species, which also exhibit quite different conceptacle morphology (uniporate and flush with the surface in Lithophyllum vs. distinctively raised and either uniporate or multiporate in Mesophyllum). Although both species occur in a similar habitat (wave-exposed, shady places in the littoral and deeper), L. stictaeforme is more frequently found and appears to be a Mediterranean endemic as its presence on the European Atlantic coast, the Canaries and the Azores is unknown (or unconfirmed, Athanasiadis 1999b). On the other hand, all collections of M. expansum from the Mediterranean are either tetrasporangial or sterile (Cabioch and Mendoza 2003; present study). This suggests that the two species have different centers of distribution as also supported by the fact that gametangial thalli of $M$. expansum were found in the Canaries. Further studies are needed to confirm this hypothesis - in particular the Banyuls material of Feldmann (1939: 309) referred to 'Mesophyllum lichenoides...[avec] des conceptacles à cystocarpes en mars'.

Most of our data largely confirm Cabioch and Mendoza's (2003) study, but we have also to report a discrepancy in the number of rosette cells that, according to these authors, is '8-9'. As this 'low' number contradicts their illustration (Cabioch and Mendoza 2003: fig. 3B) where 11 rosette cells are evident, matching instead the number shown for $M$. lichenoides (Cabioch and Mendoza 2003: fig. 3E), we believe their statement to be a typographic error.

Mesophyllum expansum in the Canaries and Morocco The thalli from Tenerife are not as large as those recorded from the Mediterranean, but are both tetrasporangial and gametangial, indicating that the Canaries are within the center of distribution of the species. All collections examined come from the upper sublittoral and littoral zones at 'Orotava' (now Porto de la Cruz) - Børgesen (1925: 3 ), being unsuccessful with his dredging attempts, collecting almost daily at Orotava 'during low-tide, weather and sea permitting', and all recently collected specimens found at TFC are from the same area where the species grows luxuriantly in the rock-pools just in front of the main harbor of 
the city (J. Afonso-Carrillo pers. comm.). On the other hand, Pinedo et al. (1992: 42) reported 'Mesophyllum lichenoides' mainly from deeper habitats, but we have not located any of their collections in TFC. Cabioch and Mendoza (2003: 259) have reported the species from Mazagan in Morocco (coll. Hamel, 1939, material at PC), but other information from this region is not available (see also Footnote 1).

Mesophyllum expansum in the Azores The four tetrasporangial records of Mesophyllum expansum from Pico, São Miguel and Graciosa range from depths between 5 and $30 \mathrm{~m}$ and differ from those in Tenerife or the Mediterranean (where the species is also common in the intertidal). On the other hand, these distantly located, deep records probably indicate that the species is widespread in the Azores, but not abundant. The lack of gametophytes suggests that it may have its northernmost distribution here.

Mesophyllum expansum in the Western Atlantic? We have located an undated sterile specimen at BM annotated 'West Indies'. Its thallus is fragmented and composed of anastomosing, superimposed lamellae, 200-270 $\mu \mathrm{m}$ thick, displaying a predominantly coaxial hypothallium with cells 20-42 $\mu \mathrm{m}$ long and 4-8 $\mu \mathrm{m}$ broad producing an ascending perithallium up to $50 \mu \mathrm{m}$ thick, with subepithallial cells up to $21 \mu \mathrm{m}$ long, each supporting a single flattened epithallial cell 7-10 $\mu \mathrm{m}$ in diameter and 3-4 $\mu \mathrm{m}$ long. Contiguous perithallial or hypothallial cells display cell fusions and trichocytes are lacking. Amongst these features, the thin perithallium and the length of hypothallial cells match the description of Mesophyllum expansum rather than the western Atlantic M. mesomorphum (Foslie) Adey - the latter species possessing hypothallial cells up to $20 \mu \mathrm{m}$ long and a well-developed perithallium (up to $500 \mu \mathrm{m}$ thick) to receive the embedded conceptacles, whereas in $M$. expansum the perithallium is less than $150 \mu \mathrm{m}$ thick and older conceptacles deteriorate. Two other characters distinguishing these two species are the size of tetrasporangial conceptacles (850-1300 $\mu \mathrm{m}$ in $M$. expansum vs. $310-750 \mu \mathrm{m}$ in $M$. mesomorphum) and the number of rosette cells (generally or in $90 \%$ of cases, $9-11$ in M. expansum vs. 7-8 in M. mesomorphum; Chamberlain in Athanasiadis 1999a: 247, fig. 18), but as the 'West Indies' material is sterile we are reluctant in considering it as an indisputable record of M. expansum given that the species has not been reported previously from the tropical Atlantic and no material from this region was found in a study of Mesophyllum collections in the herbaria of Børgesen, Foslie, Howe, Lemoine, Taylor and D. Ballantine (in $\mathrm{C}$, L, MICH, MSM, NY, PC, and TRH). Besides, we need also to recall the occurrence of a 'Mesophyllum megacavum Suyemoto et Townsend' sp. ined. from North Carolina, provisionally described in Suyemoto's (1980: 6-10) M.S. thesis. According to the original account, this putative new species displays a habit similar to $M$. expansum (i.e., leafy thallus with superimposed lamellae) and large tetrasporangial conceptacles (650-1000 $\mu \mathrm{m}$ in external diameter), but unfortunately no specimens were located at DUKE for a closer examination (R. Searles pers. comm.).
Relationships to Mesophyllum lichenoides Despite numerous studies on the morphology and anatomy of Mesophyllum (Lithothamnion) lichenoides (Suneson 1937: 62-68, pl. IV fig. 14, Cabioch 1972: 223-228, pl. X figs 1-5, Woelkerling and Irvine 1986, Woelkerling and Harvey 1993: 575, figs 30, 31, Chamberlain and Irvine 1994, Cabioch and Mendoza 2003), several characters of the species have been poorly described or documented, and so it was necessary for us to collect information for a comparison. Our material is from Jersey, Roscoff, Trez Hir, and Cabo Higuer, and has a far more restricted distribution (than that reported in the literature for the species). The type locality of the species is Cornwall, UK, and its northernmost record on the European continent is currently accepted to be in Holland (Stegenga et al. 1997: 29, drift specimens), though it reaches the Orkney Islands off the northern coast of Scotland (Chamberlain and Irvine 1994: 202-204). The southernmost record, according to our study, is Cabo Higuer (on the border between Atlantic France and Spain). In our specimens, individual lamellae are up to $265 \mu \mathrm{m}$ thick, composed of a predominantly coaxial hypothallium (80-220 $\mu \mathrm{m}$ thick; hypothallial cells 15$25 \mu \mathrm{m}$ long; Figure 16), producing an ascending perithallium up to $45 \mu \mathrm{m}$ thick, with subepithallial cells up to $17 \mu \mathrm{m}$ long, each supporting a single epithallial cell, more or less isodiametric (5-7 $\mu \mathrm{m}$ in diameter; Figure 17). Cell fusions between contiguous perithallial or hypothallial cells are common and trichocytes are absent. Gametangial thalli dioecious. Carposporangial conceptacles 750-1050 $\mu \mathrm{m}$ in diameter and 225-350 $\mu \mathrm{m}$ high, with chambers 470-550 $\mu \mathrm{m}$ in diameter and 230-320 $\mu \mathrm{m}$ high, and a central 'pedestal' (n: 6) (Figure 18). Carposporangia formed at the periphery. Roof 70-140 $\mu \mathrm{m}$ thick with a central conical ostiole 70-100 $\mu \mathrm{m}$ in diameter, forming papillate cells near the base. The latter 10-22 $\mu \mathrm{m}$ long and 3-5 $\mu \mathrm{m}$ broad, attached singly to basal cells, 3-7 $\mu \mathrm{m}$ long, and projecting into the chamber (Figure 19). Male conceptacles 650-980 $\mu \mathrm{m}$ in external diameter and 160-280 $\mu \mathrm{m}$ high, with chambers 370-700 $\mu \mathrm{m}$ in diameter and 90-120 $\mu \mathrm{m}$ high (n: 7). Male structures simple, occurring both on the floor, the walls, and the roof (Figure 20), at maturity displaying characteristic lunate SMCs (Figure 21), which at the end of their fertility become palisade and support remains of spermatangial walls (Figure 22). Tetrasporangial conceptacles 640-1320 $\mu \mathrm{m}$ in external diameter and 250-310 $\mu \mathrm{m}$ high (n: 10), with chambers 520-800 $\mu \mathrm{m}$ in diameter and 300-380 $\mu \mathrm{m}$ high (n: 8). Tetrasporangia 180-260 $\mu \mathrm{m}$ in length (n: 9). Conceptacle roofs 52-67 $\mu \mathrm{m}$ thick, composed of 6-7 celled filaments, perforated by $29-118$ pores (n: 5). Pore plates between 440 and $820 \mu \mathrm{m}$ in diameter (n: 4). Pore canals straight with an apical opening ca. $13-18 \mu \mathrm{m}$ in diameter and ca. $25 \mu \mathrm{m}$ at the base (Figures 23 and 24). Pore openings surrounded by (6) 7-8 (9-10) rosette cells [frequency: 6 (3\%), 7 (32\%), 8 (49\%), 9 (15\%), 10 (1\%); n: 299]. Rosette cells either normal epithallial cells or 'thinner-wider' (in the former case being flush with the surface and in the latter terminating below). Pore cells lining the canals generally smaller than neighbouring roof cells, forming 7-10-celled filaments, and either 'thinner-wider' (Figures 25, 26-28, white arrows) or 'squarish' (Figures 27-29, black arrows). 

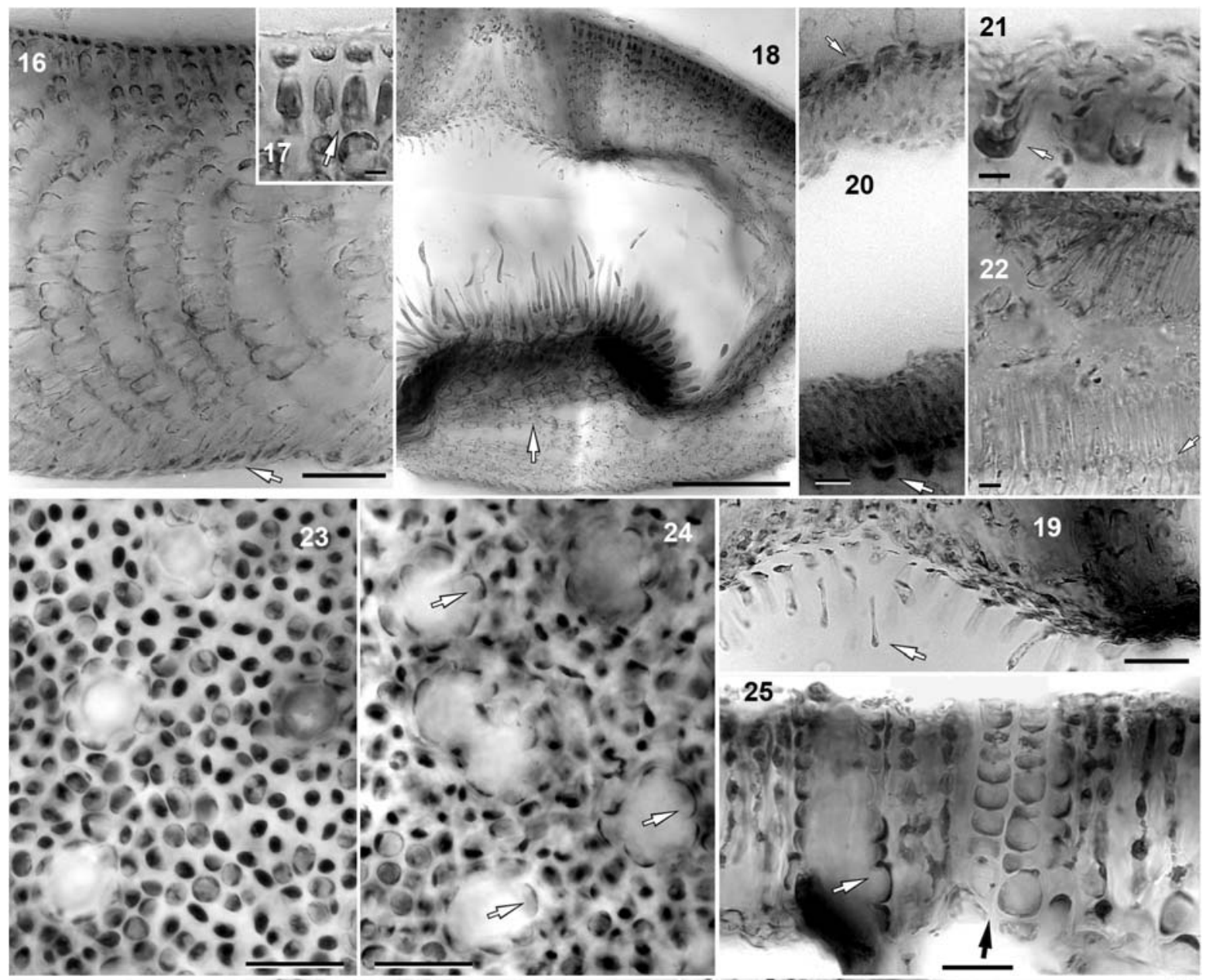

$25 \times 2$ 둥
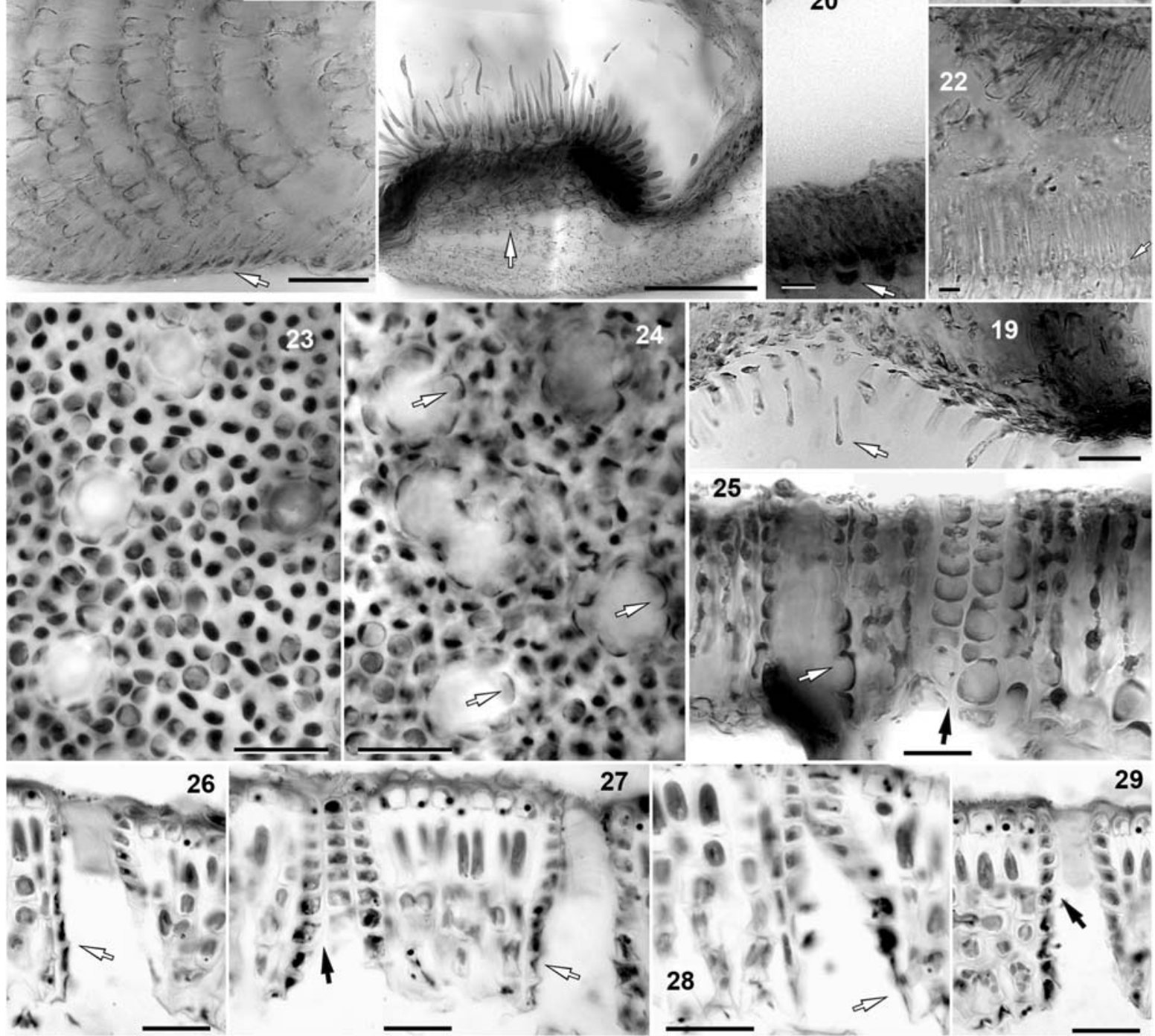

27
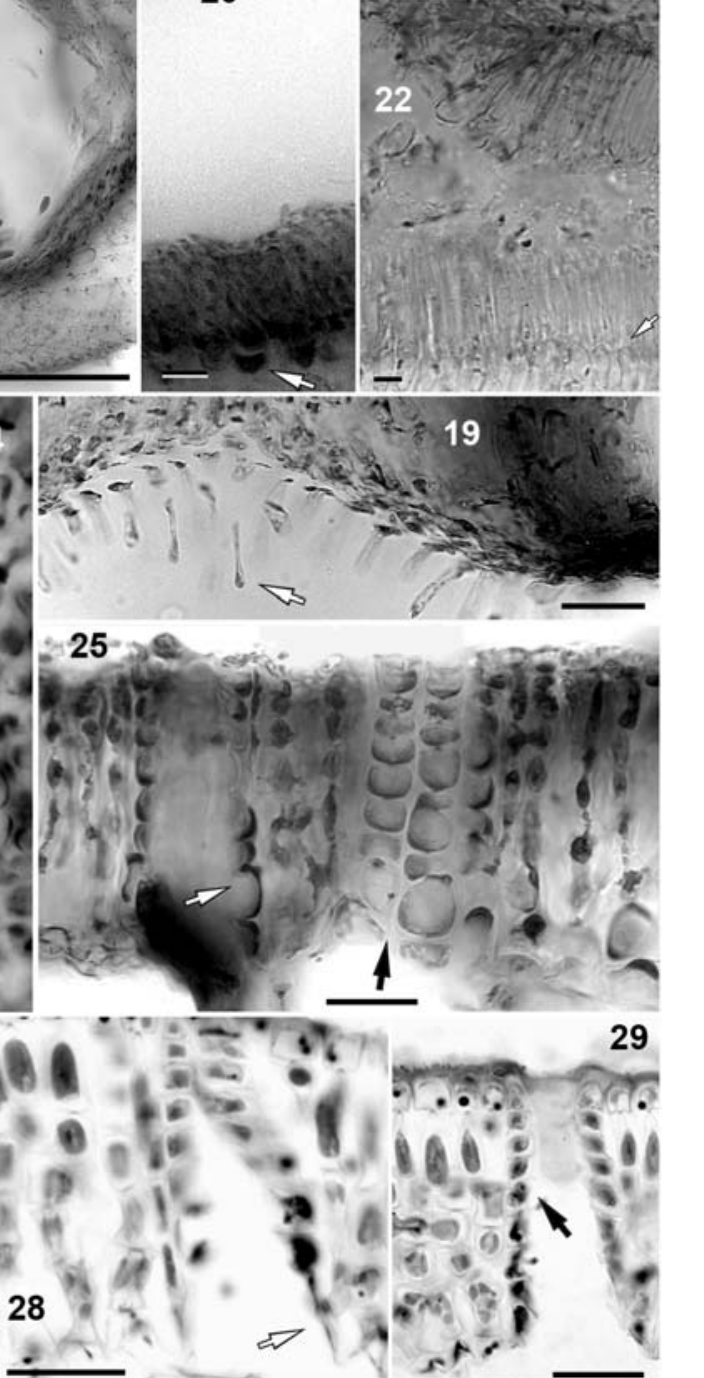
While we used methods in the preparation of our sections different from those of Suneson 1937, we observed variation in the shape and size of pore cells in Suneson's material (in single conceptacle roofs), leading us to conclude that the typical 'squarish' pore cells described for the generitype (e.g., Woelkerling and Irvine 1986: fig. 24) do not represent a stable character but rather a state - the second and more commonly found being the 'thinner-wider' type that was also observed occasionally in Mesophyllum expansum.

In contrast, we found that the number of rosette cells is a stable character (as in Mesophyllum expansum), since more than $80 \%$ of the canals are surrounded by $6-8$ rosette cells as compared to $9-11$ counted in more than $90 \%$ of the canals of $M$. expansum. We compared our results to the scanty data previously described or illustrated for M. lichenoides (Rosanoff 1866: pl. 5 fig. 6; Y.M. Chamberlain pers. comm., specimen $\mathrm{n}^{\circ} 5813$, in herb. Chamberlain; Cabioch and Mendoza 2003: 264, fig. 3E, exclusive data in the text and table 1) and found excellent agreement, so that we propose this character as diagnostic in segregating these two species.

Systematics Mesophyllum expansum belongs unambiguously to the 'boreal subgroup' of Mesophyllum (Athanasiadis et al. 2004: 161), species of which are characterized by a predominantly coaxial hypothallium and a 'pedestal' in carposporangial conceptacles. Moreover, the development of a strictly foliose thallus with unattached-superimposed growth points to a smaller taxon group that, apart from $M$. expansum, includes the generitype ( $M$. lichenoides), $M$. lamellatum (Setchell et Foslie) Adey, M. megagastri Athanasiadis (2007), M. conchatum (Setchell et Foslie) Adey, and probably $M$. mesomorphum. These six species have a restricted distribution in the warm-temperate regions of the Northern Hemisphere, which reflects their close relationship and suggests the putative presence of a common ancestor. Further progress requires comparative studies with members of the genus from the tropics and the Southern Hemisphere.

\section{Conclusion}

We examined specimens of the Mesophyllum lichenoides-M. expansum complex along and off the coast of Europe, and concur with Cabioch and Mendoza (2003) that the external habit clearly distinguishes these two species $-M$. expansum forming robust thalli up to $12 \mathrm{~cm}$ in diameter, whereas thalli of $M$. lichenoides are rather fragile and do not exceed $3 \mathrm{~cm}$ in length. In addition, we have found that the number of rosette cells is the most reliable and easily accessed character to separate these two taxa $-M$. expansum displaying more frequently (90\%) 9-11 and M. lichenoides 6-8 cells (80\%). The two species also differ in other anatomical characters such as in the shape of epithallial cells - usually flattened in $M$. expansum but rather isodiametric in M. lichenoides (in transverse section) - thallus thickness, and pore cell size and shape. However, the latter characters show variation and require section preparation for viewing, whereas conceptacle roofs can be easily removed and, after decalcification in weak acid, diagnosed under a low resolution microscope. We have found only $M$. expansum in the examined collections from the Mediterranean Sea, the Canaries and the Azores, which indicates that the occurrence of $M$. lichenoides in these regions requires confirmation. The southernmost record of M. lichenoides in our material is from Cabo Higuer, on the border between France and Spain.

\section{Acknowledgements}

We thank the keepers of the herbaria BM, C, CAT, DUKE, L, $\mathrm{MICH}, \mathrm{MSM}, \mathrm{NY}, \mathrm{PC}$, TFC, and TRH for generous loans of collections or information, and C. Rodriguez-Prieto and Y.M. Chamberlain for sending specimens from their private collections. We also thank our two reviewers and the editor of the journal for constructive criticisms and corrections on an earlier version of the present work. Financial support was provided through grants from the Captain Stenholms Foundation and Kungliga Vetenskaps- och Vitterhets Samhället i Göteborg.

\section{References}

Adey, W.H., R.A. Townsend and W.T. Boykins. 1982. The crustose coralline algae (Rhodophyta; Corallinaceae) of the Hawaiian Islands. Smiths. Contr. Mar. Sci. 15: 1-74.

Andersson, R. and A. Athanasiadis. 1992. A catalog of taxa in the Phycological Herbarium of Göteborg. Dept of Marine Botany, University of Göteborg. pp. 122.

Athanasiadis, A. 1999a. Mesophyllum macedonis nov. sp. (Rhodophyta, Corallinales), a putative Tethyan relic in the North Aegean Sea. Eur. J. Phycol. 34: 239-252.

Athanasiadis, A. 1999b. The taxonomic status of Lithophyllum stictaeforme (Rhodophyta, Corallinales) and its generic position in light of phylogenetic considerations. Nord. J. Bot. 19: 735-745.

Athanasiadis, A. 2007. Revision of Dawson's collections referred to Lithothamnion lamellatum (Melobesioideae, Corallinales, Rhodophyta). Nova Hedwigia 85: 195-242.

Athanasiadis, A., P.A. Lebednik and W.H. Adey. 2004. The genus Mesophyllum (Melobesioideae, Corallinales, Rhodophyta) on the Northern Pacific coast of North America. Phycologia 43: 126-165.

Basso, D. and G. Rodondi. 2007. Valutazione del tasso di crescita in coltura delle alghe calcaree Lithophyllum stictaeforme e Mesophyllum lichenoides: primi risultati. $38^{\circ}$ Congresso SIBM.S. Margherita Ligure, 28/5-2/6/2007. Abstract book: 82.

Børgesen, F. 1925. Marine algae from the Canary Islands, especially from Teneriffe and Gran Canaria. I. Chlorophyceae. Dan. Biol. Medd. 5: 1-123.

Børgesen, F. 1929. Marine algae from the Canary Islands, especially from Teneriffe and Gran Canaria. II. Rhodophyceae. Part II. Cryptonemiales, Gigartinales and Rhodymeniales. Dan. Biol. Medd. 8: 1-97, 4 pls.

Braga, J.C., J. Aguirre and J. Esteban. 2009. Algas calcáreas del Parque Natural de Cabo de Gata - níjar guía de campo. Junta de Andalucia Cons. de Medio Ambiente, Ministerio de Medio Ambiente Y Medio Ruraly Y Marino, Acuamed. pp. $141+63$ (English translation).

Cabioch, J. 1972. Étude sur les Corallinacées. II. La morphogenèse; conséquences systématiques et phylogénétiques. Cah. Biol. Mar. 13: 137-288, 12 pls. 
Cabioch, J. and L.M. Mendoza. 2003. Mesophyllum expansum (Philippi) comb. nov. (Corallinales, Rhodophytes), et mise au point sur les Mesophyllum des mers d'Europe. Cah. Biol. Mar. 44: $257-273$

Chamberlain, Y.M. and L.M. Irvine. 1994. Melobesioideae Bizzozero. In: (L.M. Irvine and Y.M. Chamberlain, eds) Seaweeds of the British Isles. Volume 1 Rhodophyta, Part 2B Corallinales, Hildenbrandiales. HMSO, London. pp. 159-234.

Endlicher, S.L. 1843. Mantissa botanica altera. Sistens generum plantarum supplementum tertium. Vindobonae. pp. $4+111$.

Feldmann, J. 1939. Les algues marines de la côte des Albères. IV. Rhodophycées. Rev. Algol. 11: 247-330.

Foslie, M. 1895. The Norwegian forms of Lithothamnia. Det Kgl. Nor. Vidensk. Selsk. Skr. 1894: 29-208, 23 pls.

Foslie, M. 1897. On some Lithothamnia. Det Kgl. Nor. Vidensk. Selsk. Skr. 1: 1-20.

Heydrich, F. 1901. Bietet die Foslie'sche Melobesien-Systematik eine sichere Begrenzung? Ber. Deutsch. Bot. Ges. 19: 180-194.

Heydrich, F. 1904. Stereophyllum, ein neues Genus der Corallinaceen. Ber. Deutsch. Bot. Ges. 22: 196-199.

Heydrich, F. 1911. Lithophyllum incrustans Phil. mit einem Nachtrag über Paraspora fruticulosa (Ktz.) Heydrich. Bibliotheca Bot. 18: 1-24, 2 pls.

Holmgren, P.K., N.H. Holmgren and L.C. Barnett. 1990. Index Herbariorum, Part I. The herbaria of the world. Regnum vegetabile vol. 120. New York Botanical Garden, Bronx, New York. pp. 693.

Kuntze, C.E.O. 1898. Revisio generum plantarum. III. Arthur Felix, Leipzig. pp. 576.

Kützing, F.T. 1849. Species algarum. F.A. Brockhaus, Leipzig. pp. vi +922 .

Kylin, H. 1956. Die Gattungen der Rhodophyceen. Gleerups, Lund. pp. $\mathrm{xv}+673$.

Lemoine, M. 1924. Corallinacées du Maroc, I. Bull. Soc. Des Sci. Nat. Maroc 4: 113-134, plates III, IV.

Levring, T. 1974. The marine algae of the Archipelago of Madeira. Bol. Mus. Munic. Funchal 28: 5-111.

McNeill, J., F.R. Barrie, H.M. Burdet, V. Demoulin, D.L. Hawksworth, K. Marhold, et al. 2006. International Code of Botanical Nomenclature (Vienna Code) adopted by the 17th International
Botanical Congress, Vienna, Austria, July 2005. Ruggell, Liechtenstein. pp. 568.

Neto, A.I. 1994. Checklist of the benthic marine macroalgae of the Azores. Arquipélago Life Mar. Sci. 12: 15-34.

Philippi, R.A. 1837. Beweis, dass die Nulliporen Pflanzen sind. Arch. Naturgesch. 3: 387-393, pl. IX.

Pinedo, S., M. Sansón and J. Afonso-Carrillo. 1992. Algas marinas bentónicas de Puerto-de la Cruz (antes Puerto Orotava), Tenerife (Islas Canarias). Vieraea 21: 29-60.

Rosanoff, S. 1866. Recherches anatomiques sur les Mélobesiées. Mém. Soc. Imp. Sci. Nat. Cherbourg 12: 5-112, 7 pls.

Stearn, W.T. 1986. Botanical Latin. 3 Ed. 3 Impr. David \& Charles Inc., North Pomfret. pp. $14+566$.

Stegenga, H., I. Mol, W.F. Prud'homme van Reine and G.M. Lokhorst. 1997. Checklist of the marine algae of the Netherlands. Gorteria, Suppl. 4: 1-57.

Suneson, S. 1937. Studien über die Entwicklungsgeschichte der Corallinaceen. Lunds Univ. Årsskr. N.F. Avd. 2, 33: 1-102, 4 pls.

Suyemoto, M.M. 1980. A contribution to the non-articulated Corallinaceae (Rhodophyta, Cryptonemiales) of Onslow Bay, North Carolina. M.S. thesis, Duke University, Durham, N.C. pp. ix + 88.

Taskin, E., M. Öztürk, O. Kurt and M. Öztürk. 2008. The check-list of the marine flora of Turkey. Manisa, Ecem Kirtasiye. pp. 87.

Woelkerling, W.J. 1983. A taxonomic reassessment of Lithophyllum (Corallinaceae, Rhodophyta) based on studies of R.A. Philippi's original collections. Br. Phycol. J. 18: 299-328.

Woelkerling, W.J. and A. Harvey. 1993. An account of southern Australian species of Mesophyllum (Corallinaceae, Rhodophyta). Austr. Syst. Bot. 6: 571-637.

Woelkerling, W.J. and L.M. Irvine. 1986. The neotypification and status of Mesophyllum (Corallinaceae, Rhodophyta). Phycologia 25: 379-396.

Woelkerling, W.J. and E. Verheij. 1995. Type collections of nongeniculate Corallinales (Rhodophyta) in the Rijksherbarium (L), Leiden University, The Netherlands. Blumea 40: 33-90.

Received 29 March, 2010; accepted 27 May, 2010; online first 21 July, 2010 